by changing the fraction of time that the light is on. The time constant of the decrease in serum bilirubin concentration also varies logarithmically with dose and doubles between continuous light and $25 \%$ light at constant irradiance.

\section{REFERENCES AND NOTES}

1. Behrman, R. E., Brown, A. K., Curry, M. R., Harber, L. C., Hastings, J. W., Odell, G. B., Schaffer, R., Setlow, R. B., Vogl, T. P., and Wurtman, R. J.: Final report of the Committee on Phototherapy in the Newborn. Available from NTIS, PB-237199 IAS (1974).

2. Clark, C. F., Torii, S., Hamamoto, Y., and Kaito, H.: The "bronze baby" syndrome: Postmortem data. J. Pediat., 88: 461 (1976).

3. Foote, C. S.: Photooxidation. In: Phototherapy of the Newborn: An Overview (National Academy of Sciences, Washington, D.C., 1974).

4. Jendrassik, L., and Grof, P.: Vereinfacte Photometrisch Methoden zur Bestimmung des Blutbilirubins. Biochem. Z., 297: 81 (1938).

5. John, E.: Complications of phototherapy in neonatal hyperbilirubinemia. Aust. Paediat. J., 11: 53 (1975).

6. Kapoor, C. L.: Uptake and release of bilirubin by skin. Biochem. J., 136: 35 (1973).

7. Maurer, H. M., Fratkin, M., McWilliams, N., Kirkpatrick, B., Draper, D. Haggins, J. C., and Hunter, C. R.: Effect of phototherapy on platelet counts in low birthweight infants and on platelet production and lifespan in rabbits. Pediatrics, 57: 506 (1976).

8. McDonagh, A. F.: The photochemistry and photometabolism of bilirubin. In: Phototherapy of the Newborn: An Overview National Academy of Sciences, Washington, D.C., 1974).

9. Odell, G. B., and Ostrow, J. D.: Personal communications.
10. Ostrow, J. D.: Photocatabolism of labeled bilirubin in the congenitally jaundiced (Gunn) rat. J. Clin. Invest., 50: 707 (1971).

11. Park, T. S., Padget, S., Fiorentino, T., Root, A. W., and Sisson, T. R. C.: Effect of phototherapy and nursery light on neonatal biorhythms. [Abstr.] Pediat. Res., 10: 429 (1976).

12. Speck, W. T., and Rosenkranz, H. S.: The bilirubin-induced photodegredation of deoxyribonucleic acid. Pediat. Res., 9: 703 (1975)

13. Speck, W. T., and Rosenkranz, H. S.: Intracellular DNA-modifying potential of phototherapy. [Abstr.] Pediat. Res., 10: 432 (1976).

14. Vogl, T. P.: On the dynamics of phototherapy. In: Proceedings of NIH Conference on Phototherapy for Hyperbilirubinemia - Long-Term Implications, April 24-25 1974. (To be published.)

15. Wu, P. Y. K.: Immediate and long-term effects of phototherapy on preterm infants. In: Phototherapy of the Newborn: An Overview (National Academy of Sciences, Washington, D.C., 1974).

16. The instrument consists of separate channels for each of the four spectral bands. Each channel consists of one or more Wratten filters defining the spectral band incident on a silicon photodiode. For the bilirubin band $(410-$ $500 \mathrm{~nm})$ a no. 34-A and no. 98 in series are used.

17. The authors gratefully acknowledge the partial support of this work by the National Foundation-March of Dimes (Research Grant 1-441) and by the Cerebral Palsy Foundation (Research Grant R-225-75).

18. Portions of this work were presented at the 4th Annual Meeting of the American Society for Photobiology, February 18, 1976, Denver, Colorado (Paper WPM-C1).

19. In partial fulfillment of the requirements for the M.S. degree in Bioengineering, Columbia University.

20. Requests for reprints should be addressed to: T. P. Vogl, Ph.D., Box 4, Babies Hospital, 630 West 168th St., New York. N. Y. 10032 (USA).

21. Received for publication November 3,1976.

22. Accepted for publication March 2, 1977.
Mononuclear cells newborn phosphoglycerate kinase phytohemagglutinin pyruvate kinase

\title{
Glycolytic Metabolism of Neonatal Mononuclear Cells
}

MAYA DAS, WAYNE KLEIN, AND STEPHEN A. FEIG ${ }^{(34)}$

Gwynne Hazen Cherry Memorial Laboratory and the Department of Pediatrics, UCLA School of Medicine, Los Angeles, California, USA

\section{Summary}

The mononuclear cells of newborn infants compared to those of normal adults contain diminished activity of pyruvate kinase (PK) $\left(14.9 \pm 1.2 \mathrm{vs} .22 .3 \pm 1.3 \mu \mathrm{mol} / 10^{10} \mathrm{cells} / \mathrm{min}\right)$ and phosphoglycerate kinase (PGK) (195 \pm 10 vs. $415 \pm 19)$. These deficiencies are accentuated in the cells of premature infants (4.9 $\pm 0,5$ and $71 \pm 15$, respectively) and are accompanied by reduced activity of adenylate kinase (AK) (14.8 $\pm 1.9 \mathrm{vs} .33 .6$ \pm 2.6). The activities of $A K$ and $P G K$ in adult and neonatal mononuclear cells are stimulated by phytohemagglutinin (PHA). Although the PK activity of adult cells is stimulated by PHA, the PK activity of neonatal cells is not. Mononuclear cell glycolysis is stimulated by PHA in both adults and neonates. The mean lactate production of neonatal cells is slightly lower than it is in adult cells (93 vs. $110 \mu \mathrm{mol} / 10^{10}$ cells/hr, unstimulated, and 151 vs. 181 , stimulated), but the differences are not statistically significant. The ATP content of neonatal cells $(3.8 \pm 0.4 \mu \mathrm{mol} /$ $10^{10}$ cells) is reduced compared to adult values $(6.0 \pm 0.3)$. Lactate production is directly correlated with $P K$ activity in adult and neonatal mononuclear cells. Neonatal mononuclear cell PK activity increases to adult levels during the first year of life.

\section{Speculation}

Glycolytic metabolism of neonatal mononuclear cells differs from that observed in adult cells. Pyruvate kinase may play a critical role in the energy metabolism of immunocytes. The observed increase in mononuclear cell $P K$ activity to adult values in the middle of the first year of life may suggest a correlation of $P K$ activity with maturation of monocyte function.

Infection is a major cause of morbidity and mortality in newborn infants. The increased frequency and severity of infection in neonates suggests that a major predisposing factor may be an impairment of cellular immune function. Several observations lend support to this hypothesis. For instance, graft vs. host disease has been observed after intrauterine and exchange transfusions $(17,19)$. Furthermore, skin homograft rejection is delayed in the normal newborn (7) and Uhr et al. (25) have shown diminished rate and degree of skin sensitization to dinitrochlorobenzene in neonates. The passive transfer of skin reactivity to newborns is reduced (26), and Bonforte has described decreased reactivity to PHA in premature infants (3). 
In spite of the ample in vivo evidence of neonatal immunodeficiency, in vitro evaluations of neonatal cellular immune function have not revealed overt abnormalities. The number of circulating thymus-derived lymphocytes (T-cells) is normal in the fetus of greater than 32 weeks of gestation (27). The number of B (bursal equivalent)-derived lymphocytes in newborns is also similar to adult norms (12). Indeed, the proliferative capacity of cord lymphocytes may be greater than that of adult lymphocytes $(2,5,13,14)$. There has, however, been an observation of diminished antibody-mediated cellular cytotoxicity in newborns (15) and, more recently, a report of diminished monocyte chemotaxis in neonates (11).

These studies were undertaken to compare the metabolism of cord lymphocytes with that of adult lymphocytes. Since the processes of cellular immunity obviously require energy, these experiments were aimed at detecting metabolic alterations which might suggest the physiologic basis of impaired cellular immunity in newborn infants. We report reduced levels of several energyrelated enzymes as well as diminished ATP content in neonatal lymphocytes. These abnormalities are more severe in the lymphocytes of premature infants. The physiologic correlates of these metabolic perturbations remain to be defined.

\section{MATERIALS AND METHODS}

Blood specimens were obtained by venipuncture from 50 normal adults and 23 pregnant women immediately before delivery. Blood specimens were also obtained from the placental end of the cut umbilical cord of 60 term newborns and 8 premature infants. The premature infants varied in weight from 1900-2300 $\mathrm{g}$, and were of appropriate weight for gestational age.

All blood specimens were defibrinated, centrifuged, and the buffy coat harvested. The buffy coat was applied to a FicollIsopaque gradient, centrifuged, and the mononuclear cells were isolated for further study (4). The cells obtained were $>95 \%$ mononuclear, but contained $10-20 \%$ monocytes. This was similar in both adult and cord specimens. Platelet contamination was negligible. The cells were washed in a balanced salt solution, counted manually, and viability assessed by trypan blue exclusion (1).

For enzyme assays, the sonicate of a cell suspension (0.5-1.0 $\times 10^{6} / \mathrm{ml}$ ) was used. Enzyme assays were performed in a final volume of $1.0 \mathrm{ml}$, by linking the reaction being tested with another reaction in which $\mathrm{NADH}$ was oxidized. The resultant decrease in $O D_{340}$ was measured with a Gilford recording spectrophotometer.

Pyruvate kinase was measured in a system containing $100 \mathrm{mM}$ Tris- $\mathrm{HCl}(\mathrm{pH} 8.0)(29), 10 \mathrm{mM} \mathrm{MgCl}, 100 \mathrm{mM} \mathrm{KCl}, 1.5 \mathrm{mM}$ phosphoenolpyruvate (PEP) (30), $0.4 \mathrm{mM}$ ADP (29), $0.2 \mathrm{mM}$ NADH (29), and 6 units lactic dehydrogenase (LDH) (30). Phosphoglycerate kinase was measured in a system containing $100 \mathrm{mM}$ Tris- $\mathrm{HCl}$ (29) ( $\mathrm{pH} 8.0), 10 \mathrm{mM} \mathrm{MgCl}, 1 \mathrm{mM} 3-$ phosphoglycerate, $5 \mathrm{mM}$ ATP (29), $0.2 \mathrm{mM} \mathrm{NADH}(29)$, and 4 units glyceraldehyde phosphate dehydrogenase (30). Adenylate kinase was measured in a system containing $100 \mathrm{mM}$ Tris- $\mathrm{HCl}$ (pH 8.0) (29), $50 \mathrm{mM} \mathrm{MgCl}_{2}, 20 \mathrm{mM} \mathrm{KCL}, 0.75 \mathrm{mM}$ PEP (30), 0.2 mM NADH (29), 1 mM ATP (29), 1 mM AMP (30), 3 units LDH (30), and 1 unit PK (30). Enzyme values were expressed in micromoles per min per $10^{10}$ cells.

Metabolic incubations were performed at a cell concentration of $10^{7} / \mathrm{ml}$ to minimize $\mathrm{O}_{2}$ consumption (8). The cells were suspended in Krebs-Henseleit buffer with $1 \%$ albumin and 1 $\mathrm{mM}$ glucose. Cells were incubated in a volume of $0.5 \mathrm{ml}$, and $\mathrm{pH}$ was maintained at 7.4 by the passage of hydrated warmed air with $5 \% \mathrm{CO}_{2}$ over the specimens. Incubations were performed at $37^{\circ}$ in an oscillating water bath. At appropriate intervals, specimens were removed from the water bath and rapidly centrifuged. The supernatant was separated from the cell pellet and filtrates of the supernatant were prepared by the addition of an equal volume of $6 \%$ perchloric acid. The filtrate was neutralized with $5 \mathrm{M} \mathrm{K}_{2} \mathrm{CO}_{3}$. After removal of the $\mathrm{KClO}_{4}$, the filtrate was analyzed for the content of glucose (23) and lactate (10).
The cell pellet was lysed with water, placed in a boiling water bath for $2 \mathrm{~min}$, and this solution was analyzed for the content of ATP (24). The preparation of a separate filtrate for analysis of ATP was necessary because monovalent cations severely quench the fluorescence reaction used to measure ATP.

\section{RESULTS}

Cord mononuclear cells of term infants contained diminished activity of PGK and PK compared to adult mononuclear cells (Table $1 \mathrm{~A}$ and $1 \mathrm{~B}$ ). The AK activity of cord cells from term newborns was similar to that observed in adult cells. The activities of all three enzymes were severely diminished in the cord cells of premature infants compared to cord cells of term infants.

$\mathrm{PK}$ and $\mathrm{AK}$ activities of maternal mononuclear cells were similar to adult normal controls. PGK activity in maternal cells was diminished compared to adult controls, but maternal PK and PGK activities were greater than that observed in cord cells.

The effect of phytohemagglutinin (31) on PGK, PK, and AK activity was tested in 15 paired samples of mononuclear cells from adults and term newborns. The addition of PHA to the reaction mixture caused an increase in the activity of all three kinase activities in the sonicates of adult mononuclear cells (Figs. 1-3). Similar stimulation was observed for PGK and AK activity in cord cells (Figs. 1 and 2). However, the PK activity of cord cells was not significantly increased even after exposure to as 500 $\mu \mathrm{g} \mathrm{PHA} / \mathrm{ml}$ (Fig. 3).

Glucose utilization and lactate production by adult mononuclear cells was variable from subject to subject. Conversion of glucose to lactate by adult mononuclear cells is nearly complete (Table 2). The metabolism of adult cells is promptly stimulated by exposure to PHA. The effect of PHA is maximized at a concentration of $100 \mu \mathrm{g} / \mathrm{ml}$ (data not shown). Lactate recovery from glucose appeared to be slightly reduced in the presence of PHA. Glucose metabolism of cord cells is similar to the metabolism of adult cells (Table 2). Slight apparent reductions in metabolic rate and stimulation of cord cells by PHA were not statistically significant.

Lactate production by adult and cord mononuclear cells was proportionate to $\mathrm{PK}$ activity over a wide range of enzyme activity (Fig. 4). The ATP content of cord cells was reduced compared to adult controls (Fig. 5). ATP content was measured in two samples of cord cells from premature infants. These values are extremely low but the sample number is not sufficient to make any definitive statements.

Table 1A. Mononuclear cell kinase activities in adults and newborn infants ${ }^{1}$

\begin{tabular}{lrrr}
\hline & \multicolumn{3}{c}{ Mean $\pm \mathrm{SE}, \mu \mathrm{mol} / \mathrm{min} / 10^{10}$ cells } \\
\cline { 2 - 4 } & \multicolumn{1}{c}{ PGK } & \multicolumn{1}{c}{ PK } & \multicolumn{1}{c}{ AK } \\
\hline Adult $(n=50)$ & $415 \pm 19$ & $22.3 \pm 1.3$ & $33.6 \pm 2.6$ \\
Term cord $(n=60)$ & $195 \pm 10$ & $14.9 \pm 1.2$ & $35.0 \pm 2.9$ \\
Premature cord $(n=8)$ & $71 \pm 15$ & $4.9 \pm 0.5$ & $14.8 \pm 1.9$ \\
Maternal $(n=23)$ & $313 \pm 28$ & $21.7 \pm 1.8$ & $30.4 \pm 2.4$ \\
\hline
\end{tabular}

' PGK: phosphoglycerate kinase; PK: pyruvate kinase; AK: adenylate kinase.

Table 1B. Statistical significance (Student t-test) of mononuclear cell kinase activities in adults and newborn infants ${ }^{1}$

\begin{tabular}{lccl}
\hline & \multicolumn{3}{c}{$P$ value } \\
\cline { 2 - 4 } & PGK & \multicolumn{1}{c}{ PK } & \multicolumn{1}{c}{ AK } \\
\hline Adult vs. term cord & $<0.001$ & $<0.001$ & N.S. \\
Term cord vs. premature cord & $<0.005$ & $<0.001$ & $<0.05$ \\
Adult vs. maternal & $<0.001$ & N.S. & N.S. \\
Maternal vs. term cord & $<0.005$ & $<0.001$ & N.S. \\
\hline
\end{tabular}

1 PGK: phosphoglycerate kinase; PK: pyruvate kinase; AK: adenylate kinase. 


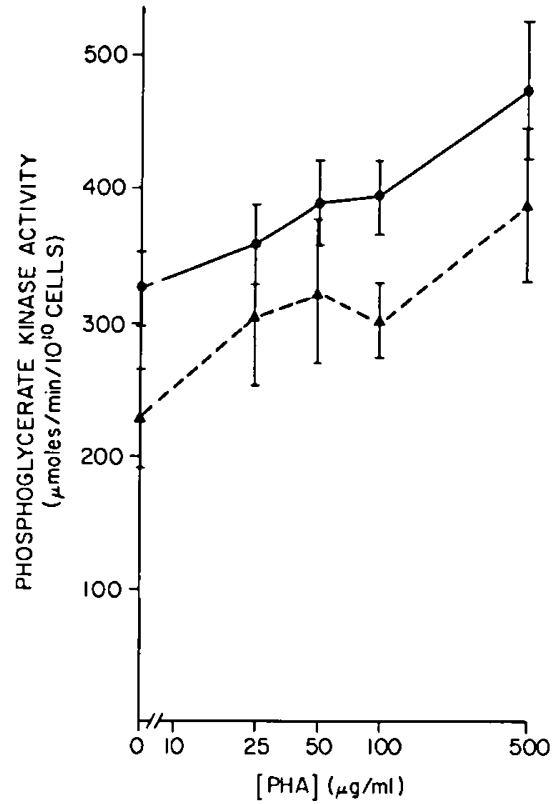

Fig. 1. Effect of phytohemagglutinin $(P H A)$ on mononuclear cell phosphoglycerate kinase activity. $-\bullet:$ normal adult $(n=15)$; $\Delta---\Delta$ : term cord $(n=13)$. Each point plotted as mean \pm SEM.

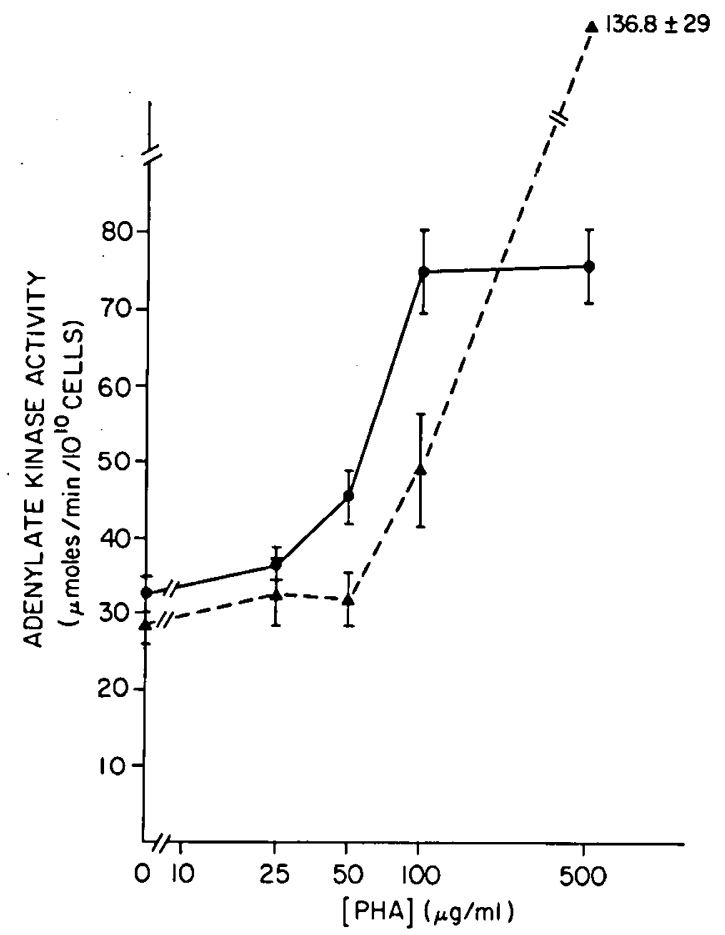

Fig. 2. Effect of phytohemagglutinin $(P H A)$ on mononuclear cell adenylate kinase activity. term cord $(n=13)$. Each point plotted as mean \pm SEM.

PK activity was measured in a small group of normal infants under the age of 12 months. The activity remains low until the middle of the first year of life, then rises rapidly to normal adult levels (Fig. 6). No infants were studied longitudinally.

\section{DISCUSSION}

The newborn infant shows evidence of immunologic incompetence. The specific mechanisms responsible for the immunologic immaturity are unclear. Metcoff (16) and Yoshida (28) observed altered leukocyte metabolism in newborns and patients

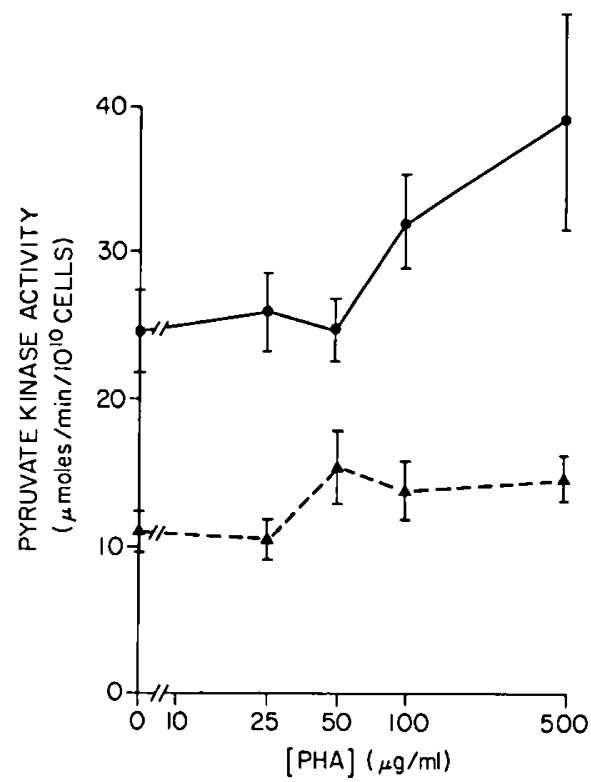

Fig. 3. Effect of phytohemagglutinin (PHA) on mononuclear cell pyruvate kinase activity. $-\longrightarrow$ : normal adult $(n=15) ; \boldsymbol{\Delta -}--\boldsymbol{\Delta}$ term cord $(n=16)$. Each point plotted as mean \pm SEM.

Table 2. Effect of phytohemagglutinin (PHA) on mononuclear cell glycolysis

\begin{tabular}{|c|c|c|c|}
\hline & \multicolumn{3}{|c|}{ Mean $\pm \mathrm{SEM}, \mu \mathrm{mol} / 10^{10}$ cells $/ \mathrm{hr}$} \\
\hline & $\begin{array}{c}\text { Glucose } \\
\text { utilization }\end{array}$ & $\begin{array}{c}\text { Lactate } \\
\text { produc- } \\
\text { tion }\end{array}$ & $\begin{array}{l}\% \text { Re- } \\
\text { covery }\end{array}$ \\
\hline \multicolumn{4}{|l|}{ Normal adult } \\
\hline No additive $(n=47)$ & $58 \pm 4$ & $110 \pm 7$ & $95 \pm 4$ \\
\hline $100 \mu \mathrm{g} \mathrm{PHA} / \mathrm{ml}(n=17)$ & $108 \pm 7$ & $181 \pm 12$ & $85 \pm 5$ \\
\hline \multicolumn{4}{|l|}{ Term cord } \\
\hline No additive $(n=10)$ & $52 \pm 12$ & $93 \pm 24$ & $89 \pm 8$ \\
\hline $100 \mu \mathrm{g} \mathrm{PHA} / \mathrm{ml}(n=8)$ & $86 \pm 14$ & $151 \pm 26$ & $87 \pm 6$ \\
\hline
\end{tabular}

with intrauterine malnutrition. They studied a broad population of white blood cells including granulocytes, lymphocytes, and monocytes. It is, therefore, difficult to draw physiologic correlations from their data.

The present studies were designed to analyze the metabolism of cells involved in cellular immune mechanisms. Recent technical advances have made the isolation of mononuclear cells feasible. However, study of this more limited population or circulating leukocytes reveals that it is still very heterogeneous. Until methods are developed for the isolation of subtypes of B- and Tcells and monocytes in quantities sufficient to perform metabolic studies, all correlations must be tentative. Nevertheless, the metabolism of the circulating neonatal mononuclear cell is clearly quite different from its adult counterpart.

The major pathway of energy metabolism in the small lymphocyte is anaerobic glycolysis (9). Glucose is converted almost stoichiometrically to lactate, which suggests that there is relatively little metabolism of glycolytic products by the tricarboxylic acid (TCA) cycle (9). The TCA cycle, however, is much more efficient than glycolysis in the production of energy, and even low levels of activity might make a significant contribution to energy metabolism.

Stimulation of lymphocytes with PHA causes an immediate increase in glycolytic activity $(18,21)$. TCA cycle activity is stimulated by PHA, but this response is delayed and, indeed, the ATP content of lymphocytes decreases in the initial period after 


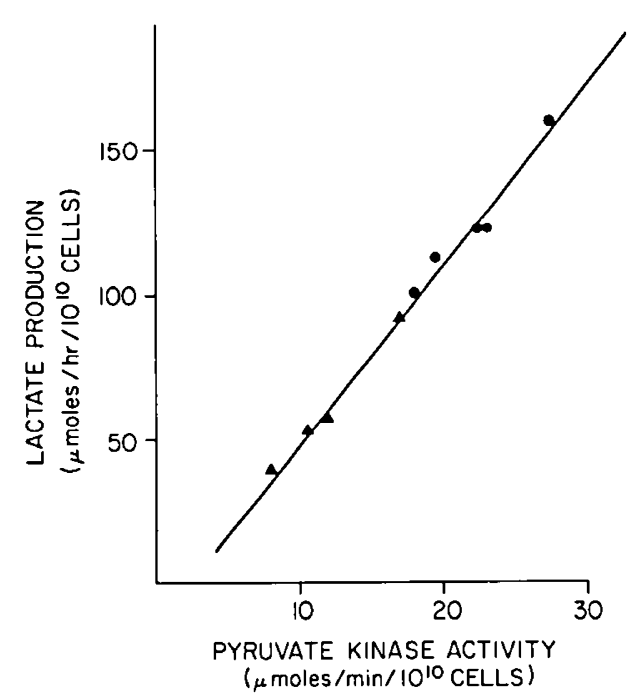

Fig. 4. Relationship between lactate production and pyruvate kinase activity in mononuclear cells. $\bullet$ : adult; $\Delta$ : term cord.

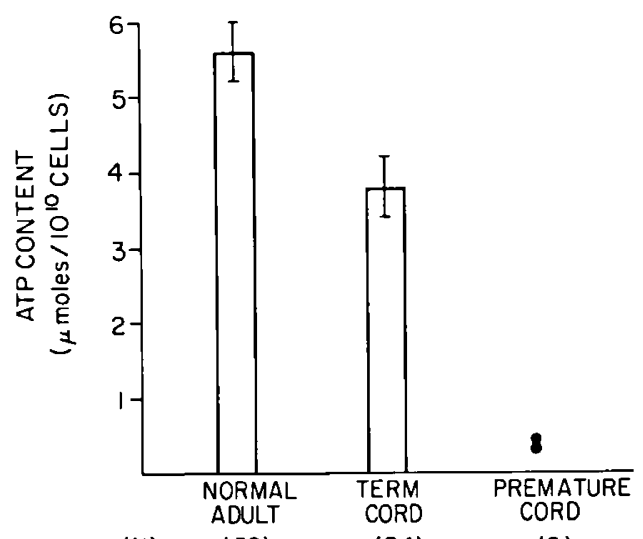

(N) $\quad(50)$

(2)

Fig. 5. ATP content of mononuclear cells. Values expressed as mean \pm SEM.

exposure to PHA (20). This suggests that glycolysis provides for the vast majority of the energy needs of the early events in blastogenesis, and that the energy needs for that period exceed the metabolic capacity of the cell. This conclusion is further supported by the inhibition of lymphocyte proliferation by incubation with 2 -deoxyglucose (22).

The neonatal mononuclear cells were deficient in two glycolytic energy-producing enzymes, PGK and PK. Cells from premature infants were more severely deficient in these enzymes and, in addition, were deficient in $\mathrm{AK}$, which mediates an energy retrieval pathway. Since neonatal mononuclear cells are larger than adult mononuclear cells (6), the concentration of these enzymes in each cell is probably even lower than is estimated by our method of expression (i.e., per cell). These enzymatic changes correlate well with the content of ATP in neonatal mononuclear cells.

PGK activity in maternal mononuclear cells, although greater than that of cord cells, was reduced compared to adult controls. The reasons for this were not investigated, but it is possible that some factor associated with pregnancy might relate to this observation. It is further conceivable, that this factor might cross the placenta and play a role in the diminution of fetal enzyme activity, but we have not tested this hypothesis. It seems unlikely, however, that some pregnancy-associated factor is involved in the diminution of cord cell PK activity, since the activity of maternal cells is normal. The reduced enzyme activities of neonatal cells might also reflect altered kinetics with

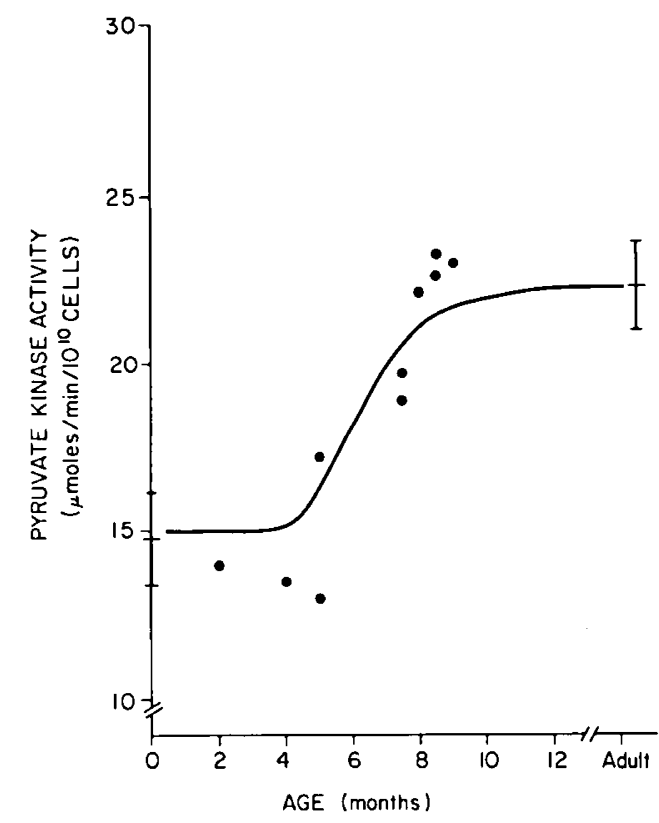

Fig. 6. Rclationship between mononuclear cell pyruvate kinase activity and age.

respect to a variety of substrates and cations. This possibility is currently under investigation in our laboratory.

PK might play a central role in mononuclear cell energy metabolism. The correlation between PK activity and lactate production is very strong. Measured PK activity of cord mononuclear cells was not stimulated by exposure to PHA. This might suggest that the metabolic deficiency is due to an alteration of function in a cell which is not stimulated by PHA, such as the monocytes. Although lactate production in resting and stimulated neonatal mononuclear cells was not significantly reduced compared to adult cells, a trend in this direction was apparent.

The relationship of enzyme activity to glycolytic metabolism remains to be clarified. Studies are hampered by difficulties in evaluating the utilization of energy by cells. The proportion of ATP utilized for most cell functions is unknown. Thus, although lactate and, presumably, ATP production is only slightly lower in neonatal cells, it may be that ATP utilization is greater and directed toward immunologically "nonproductive" tasks. This might explain the reduced content of ATP in neonatal cells compared to adult cells. In any event, energy availability (i.e., ATP synthesis plus content) of neonatal mononuclear cells is diminished.

Correlation of metabolic activity and immunologic functions has not been possible because of the difficulty in identifying a specific in vitro defect and the inability to isolate subpopulations of mononuclear cells in sufficient quantity for metabolic study. The observed abrupt increase of PK activity in circulating mononuclear cells of infants may prove to be a marker for the development of an immunologic function in the middle of the first year of life. The timing of this increase coincides with the maturation of monocyte migratory function (11). Thus, the metabolic changes observed may reflect an immaturity of the monocyte population, rather than an alteration in the lymphocytes. This possibility is currently under study in our laboratory.

\section{REFERENCES AND NOTES}

1. Amos, D. B.: Cytotoxicity testing. In: Manual of Tissue Typing Techniques. (National Institute of Allergy and Infectious Diseases, Bethesda, Md., April 1972).

2. August, C. S., Berkel, A. I., Driscoll, S., et al.: Onset of lymphocyte function in the developing human fetus. Pediat. Res., 5: 539 (1971).

3. Bonforte, R. J., Topilsky, M., Siltzbach, L. E., et al.: Phytohemagglutinin (PHA) skin test: A possible in vivo measure of cell-mediated immunity. J. Pediat., 81: 775 (1972). 
4. Böyum, A.: A one-stage procedure for isolation of granulocytes and lymphocytes from human blood. Scand, J. Clin. Lab. Invest. (Suppl. 97), 21: 51 (1968).

5. Carr, M. C., Stites, D. P., and Fudenberg, H. H.: Cellular immune aspects of the human fetal-maternal relationship. 1 . In vitro response of cord blood lymphocytes to phytohemagglutinin. Cell. Immunol., 5: 21 (1972)

6. Faulk, W. P., Goodman, J. R., Maloney, M. A., et al.: Morphology and nucleoside incorporation of human neonatal lymphocytes. Cell. Immunol., 8: 166 (1973).

7. Fowler, R., Jr., Schubert, W. K., and West, C. D.: Acquired partial tolerance to homologous skin grafts in the human infant at birth. Ann. N. Y. Acad. Sci., 87: 403 (1960).

8. Hedeskov, C. J., and Esmann, V.: Respiration and glycolysis of normal human lymphocytes. Blood, 28: 163 (1966)

9. Hedeskov, C. J., and Esmann, V.: Major metabolic pathways of glucose in normal human lymphocytes and the effect of cortisol. Biochim. Biophys. Acta, 148: 372 (1967).

10. Hohorst, H. J.: L-(+)-Lactate: Determination with lactic dehydrogenase and DPN. In: H. U. Bergmeyer: Methods of Enzymatic Analysis, p. 266 (Academic Press, Inc., New York, 1963).

11. Klein, R. B., Rich, K. C., Biberstein, M., et al.: Defective mononuclear and neutrophilic phagocyte chemotaxis in the newborn. Clin. Res., 24: 180A (1976).

12. Lawton, A. R., Self, K. S., Royal, S. A., et al.: Ontogeny of B-lymphocytes in the human fetus. Clin. Immunol. Immunopathol., 1: 84 (1972).

13. Leikin, S., Mochir-Fatemi, F., and Park, K.: Blast transformation of lymphocytes from newborn human infants. J. Pediat., 72: 510 (1968).

14. Leikin, S., Whang-Peng, J., and Oppenheim, J. J.: In vitro transformation of human cord blood lymphocytes by antigens. In: Proceedings of the Fifth Leukocyte Culture Conference, p. 389 (Academic Press, New York, 1970).

15. McConnachie, P. R., Rachelefsky, G., Stiehm, E. R., et al.: Antibody dependent lymphocyte killer function and age. Pediatrics, 52: 795 (1973).

16. Metcoff, J., Yoshida, T., Morales, M., et al.: Biomolecular studies of fetal malnutrition in maternal leukocytes. Pediatrics, 47: 180 (1971).

17. Naiman, J. L., Punnett, H. H., Lischner, H. W., et al.: Possible graft-versushost reaction after intrauterine transfusion for Rh erythroblastosis. N. Engl. J. Med., 281: 697 (1969).

18. Pachman, L. M.: The carbohydrate metabolism and respiration of isolated small lymphocytes. In vitro studies of normal and phytohemagglutinin stimulated cells. Blood, 30: 691 (1967).
19. Parkman, R., Mosier, D., Umansky, I., et al.: Graft-versus-host disease after intrauterine ane exchange transfusions for hemolytic disease of the newborn. N. Engl. J. Med., 290: 359 (1974).

20. Roos, D., and Loos, J. A.: Changes in the carbohydrate metabolism of mitogenically stimulated human peripheral lymphocytes. Biochim. Biophys. Acta, 222: 565 (1970).

21. Roos, D., de Boer, J. E. G., Huismans, L., et al.: Dose-response of lymphocyte carbohydrate metabolism to phytohehiagglutinin. Exp. Cell. Res., 75: 185 (1972).

22. Schneider, W., Pappas, A., and Scheurlen, P. G.: Hexokinase-inhibition and lymphocyte transformation. Klin. Wschr., 50: 261 (1972).

23. Slein, M. W.: D-Glucose. Determination with hexokinase and glucose-6phosphate dehydrogenase. In H. U. Bergmeyer: Methods of Enzymatic Analysis, p. 117 (Academic Press, Inc., New York, 1963).

24. St. John, J. B.: Determination of ATP in Chlorella with the luciferin-luciferase enzyme system. Anal. Biochem., 37: 409 (1970).

25. Uhr, J. W., Dancis, J., and Newmann, C. G.: Delayed-type hypersensitivity in premature neonatal humans. Nature, 187: 1130 (1960)

26. Warwick, W. J., Good, R. A., and Smith, R. T.: Failure of passive transfer of delayed hypersensitivity in the newborn human infant. J. Lab. Clin. Med. 56: 139 (1960).

27. Wybran, J., Carr, M. C., and Fudenberg, H. H.: The human rosette-forming cell as a marker of a population of thymus-derived cells. J. Clin. Invest., 51 : 2537 (1971)

28. Yoshida, T., Metcoff, J., Morales, M., et al.: Human fetal growth retardation. II. Energy metabolism in leukocytes. Pediatrics, 50: 559 (1972).

29. Sigma Chemical Co., St. Louis, Mo.

30. Boehringer Mannheim Corp., San Francisco, Calif.

31. Burroughs Wellcome Co., Burlingame, Calif.

32. The excellent technical assistance of $\mathrm{Mr}$. Theodore Henderson is greatly appreciated. We are also indebted to Ms. Mary Forest and Ms. Micheline Chamberlain for assistance in the preparation of this manuscript.

33. This research was supported in part by Grants RR 5354 and CA 12800 from the United States Public Health Service and by the Karen Brigham Memorial Fund.

34. Requests for reprints should be addressed to: S. A. Feig, M. D., Department of Pediatrics, UCLA School of Medicine, Los Angeles, Calif. 90024 (USA).

35. Received for publication December 6, 1976.

36. Accepted for publication March 2, 1977

Printed in U.S.A.

Pediat. Res. 11: 1030-1035 (1977)

Amniotic fluid arylsulfatase A electrophoresis enzymoimmunodiffusion enzymoimmunoelectrophoresis isozymes

metachromatic leukodystrophy prenatal diagnosis

sulfatide lipidosis

\title{
Prenatal Diagnosis of Metachromatic Leukodystrophy by Electrophoretic and Immunologic Techniques
}

\author{
MARIO C. RATTAZZI(49) AND RONALD G. DAVIDSON
}

Division of Human Genetics, Department of Pediatrics at Children's Hospital, State University of New York at Buffalo, Buffalo, New York, USA, and Department of Pediatrics, McMaster University Medical Centre, Hamilton,

Ontario, Canada

\section{Summary}

Electrophoretic examination of extracts of cultured amniotic fluid cells from a pregnancy at risk for metachromatic leukodystrophy (MLD) showed absence of arylsulfatase A (AS-A) activity. Immunodiffusion with anti-human AS-A immune serum failed to show enzymatically active arcs of immune precipitate. Electrophoretic studies and quantitative assay of extracts of organs from the aborted fetus confirmed the diagnosis of MLD. Electrophoresis of amniotic fluid from this and one additional fetus with MLD showed an arylsulfatase pattern qualitatively and quantitatively indistinguishable from normal. In both normal and MLD fluids, the AS-A band was replaced by a band with lower anodal mobility. Only the anodal band of normal amniotic fluid, however, reacted with the anti-AS-A immune serum in immunoelectrophoresis. Assay of amniotic fluid with $p$ nitrocatechol sulfate (PNCS) as a substrate showed marked deficiency of "AS-A" activity in the fluids from the two MLD pregnancies.

An optimal procedure for prenatal detection of MLD should 